\title{
ECONOMIC INDONESIA GOOD CORPORATE GOVERNANCE
}

In 2018, Indonesia had difficulties in opening up business fields. Indonesia is in the 73rd level out of 190 countries which fell 1 level from the previous year. It is hoped that the decline will not have a negative impact on domestic and international investors. The condition of the world economy in 2018 tended to be sluggish and unbalanced and was followed by uncertainty in world finances which were still high. The disturbance is expected to occur until now (2020). Indonesian business people are urged to continue to make reforms, innovations and create diversification in order to survive in the market. With increasing market competition, the company leaders will continue to do the company continuously in all respects to be able to support the vision and mission of the company, and also optimize the strategies that have been set to be able to get maximum profit.

Economic and business developments have experienced a rapid increase followed by increasingly fierce business competition. Only large and strong companies are able to survive in this global era, the strong global competitive environment can add to the uncertainty of the business world including digital technology, sociopolitical conditions and the emergence of new markets. Building a corporate governance system and mechanism needs to be carried out by company management to survive the increasingly fierce competition by continuing to explore company resources to create added value that is beneficial to all stakeholders.

The implementation of quality Good Corporate Governance (GCG) enables the creation of added value for stakeholders, and in turn will create sustainable business 
success (Effendi 2009). Basically, GCG is a set of rules that govern, manage and oversee the relationship between company managers and stakeholders in the company in an effort to increase company value and market valuation. By implementing GCG, companies will get many benefits, such as ensuring the formation of a corporate culture, information disclosure, an effective audit system, and risk control that always refers to GCG standards.

The scale of the transformation really depends on the level of challenges and problems faced by each company. This means that transformation can be carried out from the aspects of strategy, systems, management, organization, information technology, human resources, and funding. The transformation process is usually associated with innovative ideas and is expected to not violate business ethics and GCG principles. The transformation process must be able to fulfill the basic principles of GCG, transparency, accountability, responsibility, independence and fairness. All important guidelines that are owned, such as procurement of goods and services, GCG, ethics, internal control, whistleblowing systems, and risk management must run properly.

Based on the analysis that has been carried out by Tayibnapis et al (2020), it proves that companies that have implemented GCG are able to carry out the company's strategies and systems properly and correctly and also gain the trust of stakeholders. The implementation of GCG in companies is proven to be able to increase company value, market value, cultural value, information disclosure, audit system effectiveness, 
and risk control. Maximization of benefits can be obtained if governance runs well and is always in line with compliance and conformity to ethics and norms.

\section{DAFTAR PUSTAKA}

Tayibnapis, A.Z. \& Gora, R. (2019). Companies in Indonesia in the vortex of global economic disruption. Advances in Social Science, Education and Humanities Research. Volume 308 